\title{
Meta
}

Journal des traducteurs

Translators' Journal

\section{SARUKKAI, S. (2002): Translating the World, New York, University Press of America, XXI + 161 p. + index.}

\section{Rajendra Singh}

Volume 48, numéro 3, septembre 2003

Traduction et enseignement

Translation and teaching

URI : https://id.erudit.org/iderudit/007614ar

DOI : https://doi.org/10.7202/007614ar

Aller au sommaire du numéro

Éditeur(s)

Les Presses de l'Université de Montréal

ISSN

0026-0452 (imprimé)

1492-1421 (numérique)

Découvrir la revue

Citer ce compte rendu

Singh, R. (2003). Compte rendu de [SARUKKAI, S. (2002): Translating the World, New York, University Press of America, XXI + 161 p. + index.] Meta, 48(3),

474-475. https://doi.org/10.7202/007614ar

Ce document est protégé par la loi sur le droit d'auteur. L'utilisation des services d’Érudit (y compris la reproduction) est assujettie à sa politique d'utilisation que vous pouvez consulter en ligne.

https://apropos.erudit.org/fr/usagers/politique-dutilisation/
Cet article est diffusé et préservé par Érudit.

Érudit est un consortium interuniversitaire sans but lucratif composé de l’Université de Montréal, l’Université Laval et l’Université du Québec à Montréal. Il a pour mission la promotion et la valorisation de la recherche. https://www.erudit.org/fr/ 
authorship of translated texts, etc. Incidentally, these phenomena are addressed in this book. And of course, the cause of theory-construction would be helped by consistent use of common terms like strategy, method, etc.

Bassey E. Antia

University of Maiduguri, Maiduguri, Nigeria

Sarukkai, S. (2002): Translating the World, New York, University Press of America, $\mathrm{XXI}+161 \mathrm{p} .+$ index.

Translation Studies (TS) is a new kid on the academic block, still somewhat uncertain of her place in the academy. Precisely because her legitimacy as an academic discipline is still open to question, translation-scholars have been trying harder and producing some good work, though some of it may belong to TS only arguably. Translating the World (TW from now on) by Sundar Sarukkai (SS from now on) is a very good example of that work.

Given the contemporary modularization of knowledge and the consequent professionalization, increasingly mimicking the natural and life sciences, some would argue that TS is perhaps the only field in the human and social sciences that seems not to focus on questions of its own. Whereas the now relatively old contemporary linguistics, at least in its North-American avatar, established itself on the grounds of a maximalist insistence on its autonomy from other cognitive domains, TS seems to want to establish itself on grounds that can be said to be maximally non-autonomist. TW can be seen as the final step in that direction.

Arguments on behalf of TS provide a new window on the constant tension between the centrifugal and centripetal forces within the academy, and TW certainly invites some reflection on these forces. It is a sustained reflection on the nature of scientific discourse by someone who was trained in physics and philosophy. He tells us that in his enterprise he was helped by the vocabulary and the tools provided by modern theorizing in TS. The activity of science, he further claims, "shows striking similarities with that of translation (p. viii).Hence this review here.

Predictably SS defines translation as any activity undertaken in response to an original. For science, the original is the world; for translation in the ordinary sense, the original is the source text. Sure, there are differences between what is normally called translation and what is normally called science, but according to him, the similarities between them are, at the appropriate level of abstraction, overwhelming. The classical theories of both claim that they are quintessentially non-interventionist, but the author, drawing upon the work of contemporary continental thinkers, argues that in fact they are both necessarily mediated interpretations.

Just as the naïve view of science harbours the illusion that it can objectively transcribe the world, the naïve view of translation takes the position that translations only change the language of the text. These illusions have been shattered recently, and it is the instruments used for accomplishing that shattering that SS uses to begin an engagement where there has been almost none so far. He looks at how science constructs its meanings or embodies them in its discourses, how, in other words, theories are written in science. In order to accomplish his goal, he undertakes a detailed investigation of how science is written, read, and practiced. 
The heart of the matter, according to SS, is that scientific discourse is multisemiotic - it uses natural language, equations, charts, graphs, and other semiotic systems. It uses these varied "languages" and claims convergence of the sort that the naïve view of translation used to claim for the language-independent meaning of the source text. TS has, however, clearly shown that talk about meaning independently of the language in which it is expressed cannot be taken seriously. I have no quarrels with that demonstration or with the conclusion SS draws from it, but how about poor Wittgenstein? I don't question the claim that TS has provided rich empirical evidence for that claim, but I am not sure if people should be given credit for being unfamiliar with Wittgenstein, Weinreich and Searle! I point this out NOT to take anything away from TS scholars but to underline the fact that the conclusion in question is a fairly familiar one in semantics and pragmatics.

Although I am NOT as enthusiastic as SS is in attributing the deconstruction of Leibnitzian meaning to TS, I understand his finding it there for TS provides the context in which he finds some metaphors he finds useful in doing what he is trying to do in TW. The rich ideas about translation available now, for example, make it possible for him to come to terms with the ambiguity involved in going from mathematics to physics. He takes these metaphors and uses them to make sense of what he is trying make sense of, and does a remarkable job of it. Careful, non-polemical, and sincere throughout, his deconstruction of the discourse OF science is in fact a very effective reconstruction of the eraser of translation FROM science (ever notice/wonder what happens to the calculations of the mathematician?). It deserves to be read by everyone, though those of us who were brought up on different notions of theory and discipline will probably withhold the third cheer from what has come to be known as Translation Theory, mainly because it may not fit their notion of 'theory" and it may only arguably be about translation.

To conclude, TW is a timely, challenging, empirically grounded, and theoretically sophisticated book. As it provides an immanent critique of the practice of science, it deserves to be read together with Penrose and Bohm. Theoretically- minded scholars in TS are bound to be delighted by it, not the least because it gives them even more territory than they may have been thinking about claiming as theirs. Most people involved in the teaching and practice of translation, however, will probably find it hard to read, but they should try harder because it will be worth their while. It is a very valuable attempt to construct a third culture in which the traditions of listening and suspicion are kept simultaneously alive. One couldn't have asked for more. 